\title{
Entrevista
}

\section{A INVASÃO DA CULTURA NOS ESTUDOS DE LÍNGUA E LITERATURA: ENTREVISTA COM IRACI GAMA SANTA LUZIA}

Jailma dos Santos Pedreira Moreira (Pós-Crítica/UNEB)

Falar em cultura e educação no município de Alagoinhas, interior da Bahia, é falar em Iraci Gama Santa Luzia. A professora é reconhecida pela sua militância nestes dois campos. Iraci Gama possui graduação em Licenciatura em Português pela Universidade Federal da Bahia (1971), licenciatura em Letras Vernáculas pela Universidade Católica do Salvador (1975), especialização em Métodos e Técnicas de Ensino pela Pontifícia Universidade Católica do Rio Grande do Sul (1979) e mestrado em Educação: Métodos e Técnicas do Ensino pela Pontifícia Universidade Católica do Rio Grande do Sul (1982). Atualmente é Professora titular da Universidade do Estado da Bahia, trabalhando com temas como Leitura e produção de textos, estágio supervisionado em língua portuguesa, aprendizagem e metodologia do ensino, ensino de português etc.

No que diz respeito à educação, Iraci Gama não só se interessou em registrar todo o movimento de criação e solidificação do campus II da Universidade do Estado da Bahia, sediado em Alagoinhas, como fez parte deste movimento, coordenando, inclusive, a comissão Pró-campus universitário, de 1983 a 1994. Além disso, Iraci Gama, que ingressou na UNEB-Campus II, em 1976, quando este ainda era um germe de toda a Universidade do Estado da Bahia e se denominava Faculdade de Formação de Professores (FFPA), foi chefe de Departamento de Educação quatro vezes, coordenadora do colegiado de Letras outras tantas, e a ultima diretora da FFPA, extinta pela lei 7.176/97. Nesse percurso, não só abriu as portas para a efervescência cultural de Alagoinhas, como realizou, no campo científico, as Semanas de Educação do Campus II, participou, ministrou e coordenou aulas, cursos, projetos pedagógicos e referentes à estrutura curricular dos cursos de letras. Suas pesquisas sempre se atrelaram à educação, cultura, memória, história e artes de Alagoinhas. Iraci Gama também foi uma das fundadoras da Associação de professores de Alagoinhas (ASPA). Sua luta pela educação de qualidade e de vanguarda se ampliou do cotidiano político da sala de aula, das ruas e dos departamentos institucionais específicos para o campo da política 
legislativa, representando os interesses da comunidade, da qual ela fazia parte, como vereadora eleita do município de Alagoinhas. Por esse percurso, já recebeu, inclusive, o prêmio-título de Educadora do ano e, no rol de personagens como Anísio Teixeira, o título de professora homenageada, em 2009, atribuído pelo Conselho estadual de Educação, em consonância com o Conselho municipal.

Em se tratando de educação e cultura, sua militância é vasta. Como já apontamos, ainda que não especificamente, Iraci Gama foi elemento humano fundamental no recredenciamento da FFPA, impedindo que suas portas fossem fechadas. Depois disso, como também já assinalamos, Iraci Gama não só se empenhou em garantir, junto com outros colegas, o espaço aberto da Faculdade para as reuniões do Movimento cultural organizado de Alagoinhas, como fez parte ativamente deste, dos seus rizomas. Nessa linha de desmembramentos, junto com outros ativistas culturais e artistas, ajudou a criar diversas organizações culturais de Alagoinhas, entre elas a Casa de Cultura de Alagoinhas, da qual foi presidente durante vários anos e a própria Secretaria de Cultura Esporte e Lazer, sendo a primeira a assumir sua gestão, de julho a dezembro de 1988 e, depois, repetindo-a, de julho de 1990 a dezembro de 1992 e ainda, pela terceira vez, de janeiro de 2001 a maio de 2003. Assim, motivada pelo movimento do qual fazia parte e sempre o retroalimentou, Iraci Gama, em nome dos ideais da Casa da Cultura, assumindo a Secretaria Municipal de Cultura, Esporte e Lazer, retomou projetos também do grupo Pró-memória - mais um rizoma do (seu) movimento - como reativação da Biblioteca Pública Municipal, criação e-ou discussão a respeito da Oficina-Escola de Promoção Humana, do tombamento do patrimônio, da volta do trem de passageiros, do Mercado do Artesão, da Oficina de instrumentos musicais, do Teatro Municipal, do Parque da Cidade etc.

Dessa forma, seguindo os passos de Iraci Gama, os significativos encontros de cultura de Alagoinhas, 11 realizados, aconteceram entre 1978 e 1993 e foram promovidos pela FFPA, Casa de Cultura e/ou Secretaria de Cultura. Sua militância nessa esfera cultural-educacional já lhe rendeu também, entre outros preitos, a medalha do mérito 2 de julho, definida pela Câmara de vereadores de Alagoinhas, bem como o título de personalidade 2002, indicado pela Assembléia legislativa da Bahia. Além disso, rendeu-lhe a homenagem do Pof. Luiz Ademir, que lhe doou uma fundação, denominada, a contragosto seu, de Fundação Iraci Gama (FIGAM), e que tem seu 
objetivo relacionado à área cultural de Alagoinhas, mais relativamente à memória do município e à ferrovia. Tal fundação está instalada hoje na antiga estação ferroviária São Francisco, em Alagoinhas - espaço de luta da profa. Iraci Gama pelo seu tombamento e preservação, mediante as várias ameaças de desabamento, assim como a igreja inacabada de Alagoinhas velha. Luta que resultou em conquistas, visto que, por conta disso, Alagoinhas foi incluída, através destes dois núcleos históricos, no plano de ação das cidades históricas do Brasil, um projeto do Instituto do Patrimônio Histórico e Artístico Nacional (IPHAN), do Ministério da Cultura.

A mulher que representou as alagoinhenses no primeiro congresso sobre a mulher trabalhadora, realizado em São Paulo, na década de 1980, nos dá pistas de uma agência em intersecção, das possibilidades de abertura do e para o sujeito feminino. Seu movimento em prol da educação e da cultura alagoinhense é ininterrupto e abarca diversos caminhos que se bifurcam. É, inclusive, na estação São Francisco, na FIGAM, que se concentra um pólo de sua militância hoje. É lá que se encontram os retalhos de sua vida dedicada à educação e a cultura de Alagoinhas. São fotos, papéis, objetos, jornais, revistas, mobiliário e tantos outros artefatos que a professora juntou-guardou no seu percurso-agenciamento coletivo, que constituem hoje o Centro de Documentação e Memória de Alagoinhas - CENDOMA, coordenado pela mesma. Essa espécie de museu artesanal, potencializado pelas mãos da professora Iraci Gama e dos amigos de Alagoinhas que ela congregou, já tem um acervo com mais de 40 mil peças e representa um marco cultural, ao mesmo tempo em que clama por um aparato especializado, por recursos institucionais, bem como por uma perspectiva educacional que considere a cultura, a criação (micro)política dos sujeitos e a revisitação de um passado como demanda do presente.

Assim, considerando as demandas presentes, o contexto atual de institucionalização da malha da cultura no Brasil, do Mestrado em Crítica Cultural, na área de Letras, no campus II da UNEB, entrevistar a profa. Iraci Gama aponta para a audição de suas longas narrativas - que inclusive nos dificultaram na hora de cortar sua prosa saborosa e engajada e resumir abaixo a entrevista - e sua textualidade dispersa no seu corre-corre cotidiano, na sua agenda sempre compromissada, na sua assiduidade nas lutas pela educação e cultura e, enfim, nos seus múltiplos relatórios e textos de pesquisa e trabalho, que encontrei e consultei no Colegiado de Letras em que é lotada. A 
entrevista realizada com a professora Iraci Gama aponta para este texto disseminado que forma os sujeitos, que também precisam recompô-lo; aponta para uma reflexão entre educação, língua, literatura e cultura. Nesse sentido, mais especificamente trata da percepção da professora acerca da invasão da cultura nos estudos de Língua e Literatura. O olhar da professora, educadora, formadora de professores, da gestora e da ativista cultural se separam e se mesclam como lugares (inter)discursivos, compondo o sujeito textualizado, que retoma sua formação, seu percurso, suas intervenções e demandas críticas. Vale à pena conferir, abaixo, o partilhar desta entrevista, das inquietações e contribuições da profa. Iraci Gama, desta intervenção crítica local-global.

Jailma dos Santos Pedreira Moreira: Vamos começar nossa entrevista com a professora Iraci Gama, hoje, dia 17/02/2011, sobre o tema: invasão da cultura nos estudos de língua e literatura.Vou começar com a seguinte pergunta, Iraci, como foi que, em sua formação básica, professores de Língua portuguesa e literatura tratavam a cultura?

Iraci Gama: (...) Essa formação básica ainda obedecia a uma legislação que primava mais pelos conteúdos definidos pelo Ministério da Educação e pelas Secretarias Estaduais de Educação. Estudei em escola publica e depois, na formação mais específica, em escola particular, mas havia uma obediência a um chamado programa escolar, onde aqueles conteúdos específicos eram priorizados. Não havia esta preocupação em intercalar o elemento cultural, buscar as nossas raízes, discutir as questões, por mais que elas fossem próximas da nossa comunidade, que tivessem ligação com nossa herança cultural. Não havia esta preocupação em estabelecer esta relação, às vezes acontecia.

Eu, por exemplo, considero que os melhores anos desta relação, que eu tenho prazer de dizer que aconteceu no meu tempo, foram exatamente os primeiros anos, no curso primário, quando eu ainda era criança e não tinha possibilidade de estabelecer esta relação, de fazer este comparativo, de fazer esta transferência, digamos assim, mas a professora de minha primeira escola primária, que era Olavo Bilac, tinha cuidado de discutir conosco quem era Olavo Bilac, por que a escola tinha esse nome. Então, eu aprendi, naquele tempo, que Olavo Bilac foi o príncipe dos poetas. Ela trazia poemas 
pra gente decorar e declamar e eu aprendi, inclusive, (começa a recitar) "tal qual a chuva caída fecunda a terra no estio, para fecundar a vida o trabalho se inventou. Feliz quem pode orgulhoso, dizer nunca fui vadio e se hoje sou venturoso, devo ao trabalho o que sou." Um poema de Olavo Bilac, que eu aprendi naquele tempo.

Então, nós tínhamos que saber o nome. O nome dele era grandinho, viu, Jailma, Olavo Brás Martins dos Guimarães Bilac. Naquele tempo poderíamos perguntar: pra que serve isso? Agora, hoje, quando a gente faz certos estudos o que eu observo? Havia uma preocupação dela em trazer para aqueles meninos, de uma cidade do interior, de um bairro da periferia, uma informação a respeito do porquê daquele patrono, do porquê o nome da escola era Olavo Bilac. Então quem é Olavo Bilac, o patrono da escola? Hoje você pode procurar muita gente que não sabe porque a escola se chama, por exemplo, Luis Navarro de Brito, que foi Secretario de Educação há algum tempo, que tem inclusive relação com a nossa terra que é Alagoinhas.

Então, eu acho que nesse tempo tive algumas oportunidades com a professora Lourdes Saback, que foi desse tempo, até o terceiro ano primário, depois tive com Noquinha, já no quinto ano primário - com a professora Ana campos, que se chamava Noquinha. Noquinha tinha uma preocupação maior. Por exemplo, ela tinha uma estante na sala, com diferentes livros e ela distribuía estes livros entre os estudantes, no final de semana, de um modo geral no sábado, que era o dia da sabatina. Ela indicava, a gente já sabia o dia de nossa apresentação, então, naquele dia, nós tínhamos que falar a respeito do que lemos, dizer o que nós entendemos, dizer quem era o autor, fazíamos pesquisa a respeito do autor. Se eu considerar que isso aconteceu na década de 50, acho muito relevante isso, estou me referindo a... - Ora eu fiz admissão em 1955, então eu fiz quinto ano primário, eu tive que fazer duas vezes, porque minha família não tinha condição de botar no ginásio, porque era colégio pago, então eu fiz duas vezes o quinto ano com ela e me beneficiei de muitas outras experiências, não apenas essa da leitura, mas ela fazia a representação.

Naquele tempo nós tínhamos a visita do inspetor escolar, que ia às escolas diretamente ver como é que estava o trabalho. E ela então encenava conosco: "faz de conta que o inspetor vem nos visitar, então, alguém aqui vai ter que fazer uma saudação a ele. Eu vou escolher alguém que vai sair e, quando entrar, vai entrar como inspetor e vou escolher também alguém que vai fazer a saudação ao inspetor”. E se fosse uma 
menina a escolhida ela emprestava ainda a bolsa dela. Ela estava teatralizando, mas o que acontecia com aquilo? Você como aluno, naquela época, com todas as dificuldades que havia, os acanhamentos, até porque o ambiente familiar não era tão propicio, a gente não tinha a televisão para estimular a fala, o que se tinha mesmo era programa de rádio, então uma professora que agia desta forma, nos levava a criar na mente aquela possibilidade de ação e também a produzir mentalmente aquele texto, também criar uma postura e vir e fazer aquela representação ali. E quem estava na sala que ia receber a autoridade tinha que usar uma linguagem que correspondesse ao nível de importância da figura que estava nos visitando. Tudo isso era exercício mental, exercício de criação, de utilização do recurso da oralidade. Você também estava, diante dos colegas e da própria professora e da visita, tendo que se posicionar, logo você estava usando da tribuna para falar, tinha que se cuidar, não podia falar de qualquer jeito.

Também ela criava as condições para você fazer um trabalho, digamos assim, não estou me lembrando qual era a citação que ela usava, mas tinha os dias em que podíamos declamar, podíamos cantar, se alguém sabia tocar, tocava... Eu, desse tempo, tenho lembranças de um menino que declamava muitíssimo bem. Antônio, era filho de Vitor Nascimento, morava pertinho da escola. Ele era muito compenetrado, declamava um poema... - Ela, a professora, ensinando a cuidar dos animais, a dar proteção para os animais, trazia uma gaiola vazia, mas botava alguma coisa lá dentro para dizer que era um passarinho - e esse poema que ele declamava era exatamente o passarinho se lamentando por estar preso. E depois de declamar aquele poema todo ele abria a porta da gaiola e o passarinho voava. Mas o menino declamava com tanta emoção, que a gente também se emocionava e chorava. Então, são momentos que eu acho que na hora que aquela professora estava criando aquelas condições, ela estava nos colocando em contato com os artistas, com os produtores culturais, com os escritores... Esta é a lembrança mais forte que tenho desta relação da minha formação, ou seja, estou me referindo ao curso primário.

Agora, eu não saberia contar um só episódio do meu tempo de ginásio e nem mesmo da minha formação, no ensino médio, no curso pedagógico, como professora, que foi, na verdade, a ocasião em que eu estudei literatura: era aquele estudo maçante, de decorar, de estudar as escolas literárias. E como eu vinha desta base, de ter a oportunidade de fazer o que sempre gostei de fazer, que foi de cantar, de falar, de 
declamar, eu vinha deste tempo, então eu me oferecia, eu queria fazer isso - Ó, eu sei um poema! Então, no dia 14 de março, ainda no ginásio, eu perguntei a professora se não ia comemorar o dia de Castro Alves, por que na escola primária a professora Noquinha nos ensinou todos os hinos: (começa a cantar) "Ó, Castro Alves, ò, Castro Alves! Salve, salve gênio altivo e varonil! Salve, salve, ó, Castro Alves! Glória imortal do Brasil!” Isso eu aprendi há um século, Jailma, mas era aquela empolgação, aquela professora entusiasmada que era para com essas coisas. Pois então, você vibrava com aquilo. Aí então, dia de Castro Alves, eu me metia a dizer: Vamos cantar o hino, que ninguém sabia - e o poema Castro Alves, e os poemas! E eu tinha 9 anos de idade, quando eu aprendi o poema O Livro e a América e sabia declamar as dez estrofes, cada uma com dez versos.

Mas, tudo isso eu tinha aprendido lá nos meus anos da escola primária e trazia isso pra casa. Em casa meu pessoal lia pra gente, eu aprendi muita coisa no tempo que eu não sabia ler, porque minhas tias liam pra gente. Então, eu tinha este ambiente sadio, de vivência e de relação com a comunidade, uma relação, eu diria forte, no curso primário, mas no ginásio e no curso pedagógico isto foi se eliminando. Então, na minha formação para colocar uma relação entre... Eu posso lhe dar ainda um outro dado interessante que são as festas populares que a escola considerava: o São João, o Santo Antônio, que era o padroeiro de Alagoinhas. Minha família não era católica, mas a escola fazia aquelas comemorações e eu participava delas, tanto que tinha uma vizinha que rezava o Santo Antônio - dona Jilu vinha pedir ao meu avô para eu participar da reza, porque eu tinha boa voz e ela dependia de mim pra puxar os cânticos. Naquele tempo os cânticos eram em latim e eu aprendi quanta coisa!

Tudo isso foi importante em minha vida, porque era um mundo que se descortinava sem preconceito. (...) Às vezes, quando a gente está já idoso e que idealiza alguma coisa e faz, aquilo fica na memória. Olha, quando eu já estava diretora da faculdade, organizando os eventos do forró da Casa da Cultura, (toda quinta feira tinha a Quinta Sanfoninha do Forró), mas quem organizava o espaço era eu. Eu que fazia os cartazes, que botava Santo Antônio, via quem é que ia homenagear na época. Aí quando eu me via realizando aqueles trabalhos, vinham aquelas lembranças... Uma vez eu fiz um altar belíssimo na festa de Santo Antônio e botei Santo Antônio e lá a gente fez o forró também... Aí as pessoas até pensam: são reminiscências que ficaram aí 
nessa memória. Entretanto, quando a agente busca, essas coisas boas vêm, vêm no trabalho, na força da escola, por isso que eu acho que é tão importante que o professor se dê integralmente ao que ele está fazendo. Não se poupe, se você tem pra dar, dê, porque as conseqüências ficam aí.

Como disse, as conseqüências boas ficam aí. Eu mesma acho que sou uma conseqüência boa: o que há de bom em mim é por consequiência do trabalho destes bons profissionais que passaram pela minha vida. Então, com estas comemorações o que a gente aprendia? Aprendia que esses eventos eram eventos da nossa comunidade e que a gente precisava considerar e respeitar. No sete de setembro, a gente vinha pra rua, não sabíamos marchar, mas vínhamos pra rua, porque era o dia da pátria, era preciso reverenciar esse dia tão importante da independência e o orgulho maior era a hora de colocar o lacinho verde e amarelo no peito. Então, eu acho que a relação que eu tive com estas questões da nossa memória cívica, da nossa memória cultural, da nossa história, esta relação, eu tive muito próxima a mim, quando na escola primária.

JSPM: E na sua formação universitária, você tem alguma imagem deste período no que diz respeito à relação entre literatura e cultura nas aulas de Língua e Literatura?

IG: Nas aulas de língua eu tenho uma lembrança... - não vou dizer uma só, pra não ficar muito mesquinho - eu tive a sorte de fazer dois cursos de língua portuguesa. Na verdade o curso do PREMEM ${ }^{1}$ tinha esse nome, Língua Portuguesa, e o curso que eu fiz na Católica era um curso de Letras. (...) Mas eu tive uma coisa que foi muito importante, uma sorte, eu diria: os professores com quem estreitei relações, no primeiro curso, eram os mesmos professores do curso pleno. O curso do PREMEM era um curso intensivo de um ano. Eram nove horas diárias de aula, incluindo os sábados. Então foi um curso muito puxado. E, em certo sentido, no curso do PREMEM eu tive contatos mais estreitos com a literatura do que no próprio curso de graduação plena, mas eram conteúdos em que a literatura em si estava valorizada, havia uma preocupação em se trabalhar determinados autores, também aquela marca de períodos, a questão das escolas... Não era tanto você estabelecer uma relação entre a literatura e a cultura, estabelecer um parâmetro entre... Por exemplo, a gente fala tanto de Castro Alves, o

\footnotetext{
${ }^{1}$ Programa de Expansão e Melhoria do Ensino Médio.
} 
poeta dos escravos, mas não se tem esta preocupação: por que ele foi importante? Por que isso que castro Alves disse...? Entendeu? Então, isso não se fazia, talvez por isso sentisse falta dessa relação.

Quando eu passei a ser professora e trabalhava com texto, aí eu estabelecia essa relação com aquela época pra trazer pra hoje, para o nosso cotidiano. Você fala de escravidão, escravidão foi só aquela que aconteceu? E hoje, quantos tipos de escravidão ainda há por aí? Assim, eu sentia falta de algo mais, embora não tivesse naquele tempo a mentalidade, é claro, que eu tenho hoje, mas aquilo ficava um pouco no vazio. Agora, alguns professores, dessa época, tanto em Língua quanto em Literatura, eram pessoas muito competentes e aquilo me dava muito prazer. (...) Mas, há um dado que eu preciso colocar aqui. Estes professores já vinham comigo desde anos anteriores, porque em 1968, a professora Joselice Macedo Barreiros, que era doutora em Linguística, veio dos Estados Unidos. Tinha conseguido uma verba da Ford e montou aqui um programa de atualização para professor. Um programa de atualização e revisão linguística para professores leigos, professores que ensinavam português, mas não tinham feito nenhum curso universitário. E eu entrei neste rol, porque era professora de Português sem nenhuma formação universitária. (...) Então, nós ficamos dois anos. Foi a primeira vez que recebi uma orientação sobre um texto, sobre o que era um texto, como trabalhar um texto. Tive contato com Carreter, que dava uma orientação, que vinha praticamente da Espanha, de como você fazer uma leitura e descobrir o que o autor está dizendo pelas expressões que utiliza, pelas relações que estabelece entre os elementos, os parágrafos.

Então, eu fui recebendo esta orientação e deste curso de Lingüística aplicada, participavam estes professores. Quando eu fui fazer o curso do PREMEM, me encontrei novamente com eles, foi um trabalho mais aprofundado e eu me senti à vontade, porque já os conhecia. E depois, quando fiz o curso na Católica, logo um ano depois, também encontrei muitos desses professores. Assim, eu acredito que o fato de ter esta aproximação com eles facilitava a discussão (...). Mas, dentro mesmo disso que você está me questionando eu não sentia esta relação.

Eu tive uma professora que eu adoro até hoje, Ívia Iracema, que é uma mulher espetacular e até hoje está atuando, no $\mathrm{NEIM}^{2}$, (...) uma hstória na minha vida, uma

\footnotetext{
${ }^{2}$ Núcleo de Estudos Interdisciplinares sobre a Mulher, da Universidade Federal da Bahia - UFBA.
} 
professora que eu conheci há tantos anos, com aquele mesmo afã, aquele mesmo entusiasmo, aquela mesma disposição, então eu tenho que reconhecer isso.

Mas o trabalho era a literatura pela literatura. Não havia essa abertura que a gente procura ter hoje de trazer essa literatura e considerar outros elementos como literatura. A gente praticamente só considerava literatura a produção dos "chamados clássicos", que obedeciam a um determinado cânone, então esses eram os literatos e os outros... Então, não se trabalhava uma revista em quadrinhos, não se pensava nisso, em revistas como Sabrina. Mas aí, quando eu fui trabalhar no Polivalente eu fiz tudo isso. Botei meus alunos para ler revista em quadrinhos, entendeu? Então, eu acho que isso tudo foi muito importante, mas não preenchia uma necessidade interior que eu tinha e que talvez eu não percebesse, na época, que eu tinha um interesse de ver outras coisas, mas quando assumi a tarefa de professora, aí fui procurando realizar estas outras leituras. Trouxe pra sala o horóscopo. Vamos discutir o horóscopo! Fazia trabalhos com o horóscopo em sala e até ia desmistificando um monte de coisa, mas sempre com aquele trabalho que muitas vezes contrariava o ensino padrão do meu tempo. Como no caso da língua portuguesa, que nós tínhamos que decorar a função do que, a função do se. Aquilo me incomodava demais, mas decorar pra quê? Mas tinha que fazer, fazia. Quando chegou na minha hora fui dando um basta nesse negócio de decorar que isto não é o mais importante.

JSPM: Considerando Alagoinhas como um pólo cultural e educacional, você tem algum dado de pesquisa que nos revele como o professor de língua e literatura trabalha a cultura na escola?

IG: (...) Você sabe que eu fiquei aqui nesses anos todos supervisionando estágio e supervisionar estágio nos leva pras escolas e pra fazer este acompanhamento. (...) Mas, eu não sentia diferença entre o trabalho que tinha sido feito no meu tempo de estudante e o trabalho que estava sendo feito. Ou seja, ainda não havia mudança naquela proposta de trabalho A relação entre língua, literatura e cultura não estava acontecendo. E eu não sei lhe dizer se há esta diferença nos dias de hoje. Pode ser até que algum professor faça um trabalho assim, mas em tese ainda continuamos naquela linha de priorizar as escolas, os autores... A linha ainda é a mesma, porque, muitas vezes, o professor, 
embora tenha uma outra orientação e queira fazer de outra forma, ele não sai deste padrão. A mudança em educação - isto não sou eu que estou dizendo, os estudiosos dizem isso - sempre é muito difícil. Mudar em educação é muito difícil, mas se não houver, da parte do profissional, este interesse em mudar, a mudança não vai ocorrer mesmo nunca!

Então, nós hoje temos os chamados temas transversais, os parâmetros curriculares, que servem de suporte para você realizar esta passagem, para você estabelecer esta relação direta, mas isso não acontece como uma etapa do trabalho que você esta montando, digamos assim, do programa que você estabeleceu para sua disciplina Não quero dizer que as escolas não realizem trabalhos em que estes conteúdos sejam valorizados. Então, é possível trazer alguém da comunidade para fazer/dar uma entrevista, fazer uma palestra. Eu mesma já fui várias vezes a algumas escolas para falar da memória de Alagoinhas. (...) Mas, o que eu não percebo é uma relação direta entre estes conteúdos e aquele trabalho que está sendo realizado pela escola. Fica como se fosse algo isolado, realizado por um determinado professor e que termina se perdendo no contexto, porque não é aproveitado pelos demais, não faz parte, digamos assim, do projeto pedagógico da escola, que hoje se coloca tanto isso, mas ainda é algo muito fictício.

Você discute, gasta tempo na jornada pedagógica, bota tudo isso no papel, depois bota tudo na gaveta. Por isso que eu fui levada a fazer uma fala, agora, lá em Lajes. Levada por Rose, uma ex-aluna nossa, (...) e eu terminei dizendo lá: - não sei se o pessoal não gostou muito - olha, existe uma determinação pra fazer o projeto político pedagógico, mas a gente não tem que fazer o projeto só porque o governo está mandando, a gente precisa conhecer a realidade desses nossos alunos, saber quais são as necessidades mais imediatas deles, para que a gente trabalhe sobre isso. É importante também descobrir quais são os propósitos dessa gente, pra onde esse pessoal aqui pode avançar, de que forma que eu posso contribuir, que tipo de conteúdo, que tipo de atividade, de oficina, eu posso realizar. Quer dizer, de que forma eu posso aproveitar tudo isso. Mas isso deve ser obrigação de todos, entra no projeto para ser trabalhado e aproveitado por todos os professores. Quem faz a escola não é o professor. O elemento central da escola é o estudante, mas para que a escola funcione adequadamente, é preciso o envolvimento de todos: os professores, os funcionários, os pais. Tudo isso é 
muito importante pra que a gente possa ter conhecimento dessa realidade, valorizar esta realidade, aproveitar isto que vem deles, trazer esta vivência deles pra cá pra o nosso meio.

Então, no dia que eu fui convidada pra ir para essa escola que eu fui, o que eu percebi, Jailma? Que eu estava falando e os alunos estavam, assim, me olhando. Talvez tivesse sido muito mais produtivo, se ela tivesse me perguntado: Iraci, se eu quisesse levar esses alunos no Centro de Documentação e Memória, que horário que você podia recebê-los? Aí eu teria combinado, porque eles iam se deparar com os materiais lá, não apenas o texto que é a única coisa que eu tinha pra dar pra eles, mas eles iam encontrar os objetos, as fotografias, as peças de roupa que estavam. Iam encontrar quantas fotos mais recentes, mas também mais antigas, mostrando um outro momento da cidade, um outro momento dessa história. E então por ali eles iam...

Pra colocar pra você isso dentro de uma realidade concreta, uma vez um grupinho, daquela escola Luis Eduardo Magalhães, do Barreiro, foi levado lá por um professor, e olhando tudo ali, de vez em quando eles me perguntavam alguma coisa. Eu via a diferença, porque eles estavam envolvidos, eles me perguntavam o que era do interesse deles de saber e a gente foi enriquecendo aquilo. Eles saíram de lá felizes. ( ...) Ali estavam no meio, dentro daquele contexto e era muito mais adequado, despertava mais o emocional, (...) a sensibilidade e a vontade, inclusive, de saber e questionar do que simplesmente estar diante de uma velha falando um bocado de coisas.

Então, eu sinto isso: que hoje alguns professores têm vontade de mudar este padrão, mas têm dificuldade, apesar de tantos anos que aqui na faculdade já se vem trabalhando com isso. Então, não quero generalizar, mas, do que eu conheço, não encontro essas diferenças do que era antes pra o que é hoje. Gostaria até de lhe dizer que na minha vivência percebi trabalhos extraordinários, mas isso não é muito verdadeiro. Acho até que algumas pessoas gostariam de fazer alguma coisa diferente, mas não se sentem muito à vontade, talvez por que o outro colega também não vai fazer, vai achar que elas estão querendo se exibir, querendo ser diferente e terminam fazendo um trabalho que continua sendo cansativo, maçante, e que não desperta o interesse dessa meninada que está por aí. 
JSPM: Creio que você já deu pistas para as próximas respostas, que serão relativas a perguntas do tipo: como deveria ser, na sua perspectiva, o tratamento dado à cultura, pelo professor de língua e literatura no Ensino Médio?

Olha, eu acho que este tratamento não deve ser dado somente pelo professor de língua e literatura, mas eu sei que você está no seu papel, porque esta é a sua área. Como eu já disse antes, o trabalho deve se feito no coletivo e a experiência que eu tenho sobre isso é uma experiência que só fortalece a minha idéia, que é a do colégio Polivalente de Muritiba. Quando eu trabalhei no colégio Polivalente de Muritiba, nós passávamos um mês, o de fevereiro, todos juntos discutindo e nós começávamos exatamente pelos professores de língua portuguesa, porque o colégio Polivalente não tinha o ensino médio, era só o fundamental. Então, era o professor de língua portuguesa. Nós levantávamos as temáticas, trazíamos para cá e fazíamos as adequações.

Vou colocar pra você um exemplo dos resultados que tivemos com este trabalho. Definimos o que seria importante: nós queríamos trabalhar os regionalistas. Ora, no fundamental não se trabalha a literatura de forma específica como no ensino médio, mas nós queríamos ler os romances com os alunos, discutir com eles, estabelecer a relação entre eles. Então, nós levamos como temática os regionalistas nordestinos pra pegar estas dificuldades que são muito nossas da falta d'água. Então, quais seriam estes livros, quem seriam estes autores? Decidimos: Vamos ler o Quinze de Rachel de Queiroz, vamos ler Vidas Secas de Graciliano Ramos, vamos ler Seara vermelha de Jorge Amado. Então, nós selecionamos alguns pontos e levamos pra discussão. Eram quatro professores por disciplina, quatro de Matemática, quatro de Português, de Ciências, de História - naquele tempo eram Estudos Sociais -, quatro de Estudos Sociais. Como produção final deste trabalho nós tivemos painéis lindíssimos, painéis feitos pelos alunos, pintados, desenhados, com a identificação dos estados do Nordeste. O pessoal de Estudos Sociais trabalhou o que era a seca, por que isso acontecia, quais as razões, a responsabilidade governamental, que sugestões de mudanças eles apresentavam para isso, já trabalhando a formação política destes meninos. Aí o pessoal de Ciências foi fazer um estudo sobre a água: o que era água, onde se buscava a água, o que se podia fazer para ter a água, quais os rios desse período, já estabelecendo uma relação com Estudos Sociais - até quando vejo, agora, a discussão sobre o São Francisco, me lembro que este é um assunto já muito velho, essa questão da transposição do São Francisco. E 
aí esse povo de Ciências foi fazer esse estudo todo sobre a água e o pessoal de História foi fazer uma pesquisa, também trabalhar com esta região a questão das propostas governamentais, o que já se tinha apresentado para melhorar esta situação, a chamada industria da seca, que enriquece tantos coronéis e tal. Então, foi um trabalho que, no final, a culminância desta unidade, você não tinha uma parede livre na escola, tudo coberto com estes trabalhos que foram produzidos, fora a produção musical, a produção poética, gente que escreveu crônica, gente que fez carta para Graciliano Ramos, gente que escreveu textos e musicou e apresentou.

Uma coisa que nós achamos que foi muito interessante, foi estabelecer a relação buscar pela geografia, nos Estudos Sociais - a distância de Muritiba com a região do semi-árido nordestino, aquela região mais crítica, a do Ceará, um pedaço da Bahia... e fazer uma comparação. Foram estudar o próprio município, observar como era a situação, que não tinha estas dificuldades, mas podia ter uma água de melhor qualidade. Então, era um trabalho conjunto, cada um se colocava diante do outro com naturalidade para apresentar suas sugestões e aceitar as sugestões do outro. Ou seja, essa vaidade que é tão comum entre nós, que cada um quer ser mais sabido que o outro, mais importante que o outro, não entrava, porque se entra um elemento desse atrapalha tudo.

Então, eu não acho que o professor de língua e literatura sozinhos vão conseguir fazer um bom trabalho para chegar até a comunidade, pra ouvir como esses meninos foram pra zona rural - e estou falando de Muritiba. Até hoje eles ainda tem essa herança do fumo, eles tinham uma fábrica de charuto que era uma fabrica artesanal, pois o dono da fabrica não a mecanizou para não desempregar aquela gente. Então, a gente levava os meninos para conhecer as seções, as mulheres fazendo aquelas caixinhas, com grampeador, mas eles tinham aqueles selos da Suerdieck, quando o charuto ficava todo pronto, era uma coisa linda a caixa. Então, um trabalho de real envolvimento.

O presidente da câmara de vereadores abria o espaço pra nós, levamos os alunos lá pra ele explicar como é que funciona uma câmara de vereadores, como um vereador é eleito, tanto que uma das motivações do grupo foi apresentar um projeto de lei para alterar aquela situação de lá, o que eles pensavam em fazer para mudar aquela situação de tanta seca. Isso sem falar na nossa parte de língua e literatura, porque eles fizeram uma leitura dos textos, eles fizeram um comentário a respeito do que eles entenderam, apresentaram os personagens, depois fizeram pesquisa sobre Rachel de Queiroz... - eu 
estou falando de uma época tão importante, que quando nós começamos a discutir, Rachel de Queiroz estava sendo indicada e foi a primeira mulher a ocupar uma cadeira na Academia Brasileira de Letras e que prazer foi em ver um menino chegar de manhã e dizer: professora, a senhora viu ontem na televisão? O quê, meu filho? Rachel de Queiroz... Ah, isso é que dar prazer! Quer dizer, ele está em casa, mas ele está vivendo aquilo. Então, eu acho que só quando o trabalho toca mesmo, vai lá no interior, mexe com o aluno, corresponde a uma expectativa e cria outras expectativas é que você vai poder ter um resultado positivo. E isso, Jailma, eu sinto muito, mas eu não vejo acontecer. Eu não vejo acontecer.

O Estadual já realizou trabalhos tão bonitos aqui em Alagoinhas, quando tinha as áreas de estudo, aquele pessoal das chamadas áreas práticas, no tempo em que o Centro Integrado era Centro Integrado.

(...) Então, não é pela condição de um professor de língua e literatura que a situação se modifica. Acho que o interesse dele de modificar é importante, é valioso e deve acontecer, mas é preciso que haja um interesse do coletivo, até porque o que você traz e aplica para este aluno, o importante vai ser ele poder fazer a transferência desse conhecimento, dessa informação. É isto que vai ser a aprendizagem, ele poder levar daqui pra ali e ter isso devidamente valorizado. Então, a escola precisa alcançar este ponto de ter a preocupação com um conteúdo que seja significativo para a realidade deste aluno, levando em conta que todos os professores, os diretores, os funcionários, todo mundo ali, deve estar trabalhando em função da melhoria daquele elemento central da escola, que é o estudante.

JSPM: Como educadora, atuando especificamente na área de formação de professores no curso de Letras, através de disciplinas como Metodologia e Estágio, de que modo você insere a questão cultural no trabalho com estes futuros professores?

IG: Nesses anos eu tenho procurado trabalhar com eles sempre assim: quando eles vão pra sala eles tem o contato com a escola, primeiro, pra saber, porque nós dependemos do conteúdo que a escola vai nos dar, então esta é a primeira dificuldade, porque se você vai trabalhar o conteúdo que a escola passa, você vai ficar tão preso aquilo, que você não faz nada diferente. Assim, nós sempre procuramos negociar. Por 
isso o interesse de ir para uma escola pública, porque na escola privada você não tem espaço, abertura nenhuma para mudar nenhum conteúdo e na escola pública você ainda consegue. (...)

Do ponto de vista dos alunos, o que a gente faz? Depois que ele traz de lá aquele conteúdo, a gente vai ter que trabalhar. E em língua Portuguesa ele tem, por exemplo, verbo, vai ter que trabalhar verbo. No mínimo vai ter que trabalhar verbo, vai estar conjugando os verbos. Já pensou que atraso de vida você ter que colocar o estudante pra dizer eu amo, tu amas, ele ama? Um negócio que não tem como estabelecer esta relação. Então, é preciso ver uma outra forma, você vai trabalhar o conteúdo, mas vai trabalhar de uma outra forma. Então, como que você pode buscar? Primeiro, buscando a produção deles, fazendo uma preparação. Eles podem escolher os temas que eles quiserem trabalhar, e você faz toda a preparação. Eles podem querer falar sobre algo que seja mais abstrato ou sobre algo que seja mais palpável. Digamos que eles escolham x tema. Um tema que eles gostam muito é amor, hoje se fala muito em sexo, em drogas... Mas se ele traz estes temas pra sala, você faz a seleção e ver o que a maioria prefere. Então, vamos fazer uma preparação sobre estes conteúdos. Digamos que drogas tenha prevalecido, que é uma coisa que está tão na moda. Então, vamos fazer como com isso? Você vai pegar este material e vai discutir com eles. Quanta coisa a gente pode dizer sobre isso: as chamadas drogas lícitas, não lícitas, onde é que isso acontece, as razões porque isso acontece, o que é mesmo que constitui uma droga lícita ou não, que comunidade é mais atingida por isso e tal. Pode ir detalhando este material para fazer até uma pesquisa. Vamos fazer esta pesquisa a partir do nosso próprio meio. O que eu tenho sobre isso? Tenho revistas, livros, filme, eu tenho um programa de televisão, vamos formar então subgrupos. Cada grupo vai ficar com uma parte dessa, pra fazer este acompanhamento, pra trazer pra cá. Vamos ver se nessa comunidade tem alguém, que a gente não vai botar em destaque, mas vamos ver se nessa comunidade tem alguma coisa que aconteça, se há possibilidade de fazer entrevista com alguém ou tem algum usuário que se recuperou? A gente pode fazer entrevista com esta pessoa, trazer pra cá esta experiência, ou se esta pessoa aceitar, trazê-la para ser entrevistada por nós. Mas é importante também ter um conhecimento mais profundo. Hoje tem esta questão da descriminalização da droga. (...) Então, é um tema geral que serve pra todo mundo, mas tem aquelas questões que são mais particulares, mais específicas e também você pode 
entrar em uma outra área. Por exemplo, se você levar em conta que a maconha é utilizada pelos índios e eles fazem isso com muita naturalidade, na Bolívia, o uso da coca... Então, não é apenas uma questão que você diz: eu vou combater! Não é só isso! É importante que você conheça as realidades, veja como é que isso acontece, como é que isso chegou pra nós, existem outras vertentes que dizem do aproveitamento da maconha para remédio.

Então, você tem diferentes facetas de uma mesma temática que podem ser trabalhadas, apresentados os resultados, ser discutido e transformado em uma produção de texto. Pode fazer um texto apenas técnico, você pode fazer um relatório das atividades realizadas, pode fazer um texto literário a esse respeito, você pode fazer um texto poético, uma música, se quiser. Dessa forma, você tem diferentes formas de observar este/um elemento que foi trazido por eles. E, pelo fato de ser trazido por eles, já vai ter maior facilidade de investigação, porque eles é que estão interessados no assunto. É muito importante que haja este desejo do grupo de fazer este trabalho. Então, hoje, quando a gente realiza um trabalho de estágio, a gente busca sempre ouvir esta comunidade, trabalhar em cima desses desejos que eles trazem, aproveitar estas temáticas, sempre como pesquisa e a gente vai observando a valorização dos elementos, a depender da comunidade, dos pontos de vista que se tem, da própria história dessa comunidade e este fechamento pode se dar numa atividade festiva. Mas, o importante é que uma temática, sendo trabalhada assim, você vai estar trabalhando com língua e até com literatura, pois quantas leituras você vai fazer. Portanto, literatura sem aquela noção de somente clássico, mas como o texto que você pega pra ler. Então, tem essa variedade.

Assim, hoje nós trabalhamos mais dentro desta linha e considerando o que é feito por um grupo. Por exemplo, você conseguiu formar quatro subgrupos, você vai ter a tarefa de cada um, você vai fazer o acompanhamento, mas cada um vai ter a sua oportunidade de colocar isso no papel, de fazer o seu registro. Quer dizer, o exercício da produção do texto vai ser feito por todos. Depois, na hora da apresentação, você vai ter o exercício da produção oral, não apenas do apresentar, do falar ou do ler o que produziu, mas também do colega que vai fazer o comentário crítico a respeito daquilo que foi apresentado, que foi dito, pra ele estar dizendo o que considerou negativo e positivo e apresentando suas justificativas. Então, você faz todo um trabalho que é de 
pesquisa, que é de estudo, mas também é de discussão interna, e aí se vai a socialização do conhecimento da realidade. Um trabalho até sociológico, mas também é um trabalho de língua, porque você vai ter esta produção escrita, oral. Então, a gente procura sempre estabelecer uma relação entre o que vai ser dito, ser feito, com essa realidade do mundo do aluno, do mundo em que ele vive.

Existem temáticas escolhidas que facilitam muito mais esta aproximação. Por exemplo, quando Écristio foi meu aluno de Estágio de Língua Portuguesa, ele veio conversar comigo e já tinha esta opção pelos quadrinhos e disse que queria fazer um trabalho com hip hop, que era com os meninos do Barreiro. E nós fizemos todo um trabalho. Foi um trabalho excelente. (...) Além deste trabalho, me lembrei de Écristio porque ele está agora fazendo o Mestrado e continua nesta mesma linha. Você veja, tinha esta opção, já tinha esta tendência e nós só valorizamos isso. (...) Então, é muito importante ouvir depois o aluno dizer o que ele sentiu. Quando o estudante diz pra o próprio estagiário e o supervisor como é que ele se sentiu no início, como é que ele se sentiu depois, a gente ver que valeu a pena, que surtiu efeito.

\section{$(\ldots)$}

Então, é um modo diferente de fazer o trabalho. É juntar o interesse do estagiário com o interesse do estudante que está lá, para que se possa fazer-trazer um conteúdo e se privilegie estes vários conhecimentos, estas várias informações que podem resultar em arte. Mas, a gente sabe que cultura não é só arte, mas que pode redundar neste conhecimento, desta vivência, desta realidade e de que forma se pode aproveitar isso em nossa vida, como se pode contribuir pra uma mudança de mentalidade.

JSPM: Iraci, como gestora, atuando na Secretaria de Cultura do município, durante algum tempo, você procurou articular as questões culturais à educação?

IG: Procurei. Não foi fácil. (...) No segundo momento em que eu fui para a secretaria, aí sim houve a possibilidade de fazer um trabalho articulado com a secretaria de educação e nós conseguimos fazer muitas coisas, junto com a secretaria de educação, apesar das dificuldades financeiras. Não tínhamos, como hoje existe, o apoio dos governos. Você sabe que a cultura sempre foi um elemento marginal, mas nós conseguimos fazer muitos trabalhos com as escolas, inclusive, fazendo atividades junto 
com os estudantes, fazendo atividades de final de semana nos bairros e, na hora em que a gente ia pros bairros, ia com a parte de esporte, mas ia também com atividades de leitura, de contação de histórias.

(...) Muita coisa junto à comunidade, buscando as necessidades do campo da música, do teatro, da dança, estabelecendo a relação com o pessoal que tinha o samba de roda, da periferia, que precisava de apoio. O pessoal da capoeira... fizemos um trabalho muito bom com o pessoal da capoeira, naquela época, e buscamos uma relação com o pessoal dos terreiros de candomblé, que se são marginalizados hoje, você imagine há vinte anos atrás?!

E essas atividades todas, elas eram muito relacionadas com os estudantes. Porque quando nós fazíamos os trabalhos na Faculdade, a Secretaria da Cultura, a Casa da Cultura ainda existindo e a Faculdade, nós estávamos sempre ali muito envolvidos em tudo. Eu continuava como professora da Faculdade, então quando a gente realizava essas atividades lá no auditório da biblioteca nós estávamos envolvendo toda essa comunidade estudantil. (...)

A discussão a respeito de cultura, como nós temos hoje, nós não tínhamos naquele tempo, nem tínhamos mesmo essa visão. Era muito mais a valorização do campo das artes, mas eu não sei se por intuição ou por essa formação doméstica dessas leituras, não sei o que influenciava, mas, a verdade é que sempre tive uma abertura maior pra entender que essa questão da nossa herança cultural, essa questão da religiosidade, que era importante respeitar.

\section{(...)}

Não, nós não somos apenas um elemento que é o resultado da mistura do branco, com o negro, nós temos o índio também aqui entre nós. E, considerando essas coisas todas, tem a questão de você respeitar o elemento que está na periferia, que tem o modo dele de ser, que tem aquelas histórias pra contar, sempre achei isso muito interessante. Tem aquele modo de ser, de pensar, às vezes você vê uma filosofia assim na vida do sujeito, você pensa: nossa! Mas às vezes é o que ele aprendeu no meio dele, o jeito dele de ser, que você precisa considerar. (...)

Uma das coisas que eu tenho muito forte na minha lembrança é que, na época da ditadura, o meu irmão tinha uma freguesia de disco, em Salvador, "Gioventu disco" era 
uma loja, ali, atrás da rua Chile... E ai o rapaz guardava os discos... Saia, assim, uma edição reduzida e guardava os chamados subversivos. E ele veio, no final de semana, ele veio de Salvador. Aí, segunda feira ou foi terça, não me lembro bem o dia, ele estava com esse disco, um disco de Gilberto Gil, uma composição chamada "Viramundo". Estava tocando Viramundo. E aí entrou um senhor que morava no Cajueiro, era compadre de meu avô, (...) uma pessoa muito simples. (...) E a radiola tava com esse disco e aí eu tô lá dentro mais Zé Gama conversando. Seu Luis chegou, parou na porta da sala, três degraus assim pra entrar e ai ele repetiu: "ainda viro esse mundo em festa, trabalho e pão!" Aí, nós tomamos, assim, aquele susto, nem vimos que ele tinha entrado. Ele tava repetindo o que Gilberto Gil diz em Viramundo, né? "Ainda viro esse mundo em festa, trabalho e pão.” Aí eu olhei assim pra Zé. Quer dizer, a primeira vista você não pensa que aquela pessoa, por ser uma pessoa simples, não ser escolarizada, vai entender aquela mensagem. Mas, aquela expressão dele, "ainda viro esse mundo em festa, trabalho e pão!", veio tão de dentro, que ele estava entendendo perfeitamente, como que esse mundo seria diferente se tivesse festa, trabalho e pão, né? Que é uma coisa lindíssima isso.

Então você aprender a respeitar as pessoas, as condições das pessoas, se a escola se dispusesse a fazer isso, certamente que essa violência não aconteceria. (...)

JSPM: De uma perspectiva mais ampla, o que falta, então, para que a relação Língua, Literatura e cultura seja, de fato, efetivada?

IG: O que falta? Acho que a escola deveria discutir cultura. Nós não temos informações, digamos assim, teóricas sobre cultura. Hoje mesmo, nós discutíamos lá, eu, Lithos e Jorge. (...) Nós sentimos isso: Falta é informação teórica, falta conhecimento, falta informação mesmo sobre isso. Porque há elementos que falam de cultura como sendo uma atividade artística. (...) Nós levantamos uma serie de pontos, na reunião do Conselho de cultura ontem. Eu ainda estou como presidente. Então, nós começamos a discutir sobre o mercado do artesão, depois sobre a escola de percussão Quilombo e aí, Alípio, que estava presente, trouxe a questão do Natal, que foi organizado pela Secretaria de Ação Social e não pela Secretaria de Cultura. Aí, hoje, de amanhã, Lithos disse: é, mas do modo como foi feito, ali, tinha que ser mesmo era a 
Secretaria de Ação Social, que aquilo não é cultura, aquilo é folclore. Aí começamos a discutir: mas como é que você vai dizer que uma festa natalina onde você... (...) Aí, pronto, lá vai a discussão, quer dizer, ele estava tomando por um ponto de vista, nós estávamos tomando por outro ponto de vista.

A questão das fanfarras, das filarmônicas, das bandas de música, das orquestras, tudo isso aí no campo da música. Ah, o samba de roda. Aí, ah, mas isso aí é uma atividade artística. E uma atividade artística não é uma atividade cultural? Então, o que eu sinto é isso. É que nós não temos, nem temos estudos, quanto mais amadurecimento pra saber o que é fazer cultura. Então, muitas vezes, quando a escola está trazendo o menino pra fazer a capoeira, que eu fui levantar esse exemplo, mas aí eu não estou propondo que a escola forme um grupo de capoeira simplesmente, mas que se discuta isso. O que é a capoeira, como é que ela veio? A necessidade que o escravo tinha que se defender com o corpo, porque o branco tinha as armas e o negro não tinha nada. Então, o próprio corpo tinha que servir de arma pra ele e ele foi fazer seus exercícios dentro do mato, no espaço mais aberto que é chamado de capoeira e é por isso que tem o nome de capoeira. E você acha que todo mundo sabe isso pra dizer isso, pra explicar isso? Então, veja, porque é que eu estou colocando todas essas nossas discussões de ontem e de hoje de manhã? Pra mostrar como eu sinto falta de algo consistente, que as pessoas possam conversar.

(...) Então, pra voltar a sua pergunta, eu acho isso. Eu acho que nós deveríamos ter... - Outro dia Osmar me dizia, que estava propondo que tivéssemos aqui uma disciplina, alguma coisa assim. Que para o curso novo de francês, eu espero que na hora que a gente tiver fazendo aí, montando um currículo, que a gente possa realmente colocar alguma coisa sobre isso. Eu, ontem, de noite, mesmo, quando nós estávamos na reunião do Conselho, tinha um grupo de dança, lá, em cima, trabalhando, mas parecia que davam, assim, uns pulos, que chega balançava tudo. Aí, Magdala saiu da reunião, nós estávamos naquela primeira sala da biblioteca e Magdala foi lá, em cima. Quando voltou, disse: ô Irá voltei com pena das meninas, porque você sabe a dança que estão ensinando, lá, em cima? A dança do "rebolation", né? Oferecem tudo, quer dizer, apanham umas crianças e vão ensinar uma coisa que nem precisava ensinar, porque a sensualidade tá aí tão à vontade. Então, a gente fica se perguntando: bom, isto é fazer cultura? Então, eu sinto isso: falta, a nós todos, uma fundamentação sobre o que é 
cultura, não é? O que é arte? Como é que a gente pode estabelecer essa relação, no caso, por exemplo, da secretaria? Ah, porque isso aqui é lazer, mas o lazer também pode conter a cultura. Você vai pra um show de música, que você ... Alípio, discutindo, ontem, a Quixabeira. Ele quer trazer um show da Quixabeira pra aqui. (...) Como é que você não está considerando um ritmo, um conjunto de letras, de músicas, de tudo? Quer dizer, como é que você não vai dizer que isso é a cultura daquela gente, daquele povo que tá ali na Quixabeira e que está existindo algo semelhante, em outros lugares? A Quixabeira já está tendo até subdivisões. Então, como é que se vai fazer essa distinção?

Então eu acho que nós precisaríamos de ter um pouco de orientação, de fundamentação, pra estabelecer mesmo o que é isso. Então, o Mestrado em Crítica Cultural pode ser uma das grandes contribuições. Ou seja, eu acho que uma das grandes contribuições do Mestrado em Crítica Cultural para a nossa comunidade é trazer esta discussão, facilitar mais a compreensão do que seja cultura, pra que as pessoas tenham uma maior facilidade de realização das suas tarefas. Porque, hoje, com os trabalhos do Ministério da Cultura, (...) eles produziram os textos e disseminaram isso no Brasil inteiro. Você discute desde aqui a conferência municipal, a conferência territorial, a conferência estadual, até a conferência nacional. Então, é claro que o que estava ali na base vai aparecer lá no topo, porque se vai discutindo e organizando as propostas. Então, é uma metodologia maravilhosa e uma forma de orientar as pessoas sobre o que é cultura. Que, aliás, era a pergunta que aparecia na última proposição do governo: Cultura é o quê? Cultura o que é? Não é? Então, acho que falta isso, tá faltando, a todos nós, essa fundamentação teórica sobre o que é cultura. Até pra facilitar o trabalho que a gente realiza, pra não ficar muita gente considerando que o "rebolation" é a cultura da Bahia. É duro a gente ter que engolir isso aí, mas o "rebolation" ganhou o mundo. Em tudo quanto é lugar, até nos Estados Unidos, eles mostraram aí, falando do "rebolation". Então, termina sendo esse o valor, quando não é isso que nos interessa.

Mas, eu considero que, numa perspectiva mais ampla, o que falta para que a relação língua, literatura, cultura, seja de fato efetivada, é isso: falta esse conhecimento a respeito de cultura, porque a respeito de língua e literatura já existe muita coisa aí, muita discussão, embora ainda tenhamos muitos contratempos, muitas contradições, ainda tem muita gente que não respeita o que tá sendo dito, e o que tá sendo escrito e o que está sendo desenhado, e o que tá sendo pensado, o que tá nas entrelinhas. Ainda não 
considera isso. Mas, de um modo geral, essa discussão já está bem mais ampliada. Agora, a cultura mesmo, tá faltando ainda a gente ter uma fundamentação maior. Quem sabe até esse mesmo material que o Ministério colocou à nossa disposição, ele pudesse ser trabalhado? Quem sabe se a escola resolvesse fazer uma discussão? (...) Então, na medida em que a gente tenha essa melhor fundamentação sobre o que seja cultura, também vai ficar mais fácil a gente estabelecer essa relação entre língua, literatura e cultura.

JSPM: Mas, você não acha que já tem alguma coisa sendo feita, ou seja, a gente pode dizer que hoje essa relação entre língua, literatura e cultura já se faz mais presente? Se sim, quais seriam os fatores que estariam contribuindo pra isso?

IG: (...) Pelo que eu observo, eu sinto que está diferente, sim. A diferença a gente percebe... (...) E eu acredito que é uma nova diretriz que alguns professores têm realizado aqui no curso de Letras e isso tem contribuído. A própria existência do Mestrado, embora seja de pouco tempo, mas já dá pra gente perceber essa diferença. E as pessoas até hoje falam, e se empolgam... a gente percebe a satisfação, o entusiasmo, o orgulho, a palavra é essa. O orgulho de dizer que está fazendo o Mestrado, que... Até participar da reunião de um seminário é motivo de orgulho para as pessoas, porque, elas estão sentindo uma injeção de ânimo naquele trabalho que elas gostariam de realizar, pelas informações que recebe.

Então, eu sinto, por essas manifestações, que há uma diferença, sim, e no caso de algumas escolas com quem eu tenho algum contato e que inclusive estive com vocês lá na Maria José Bastos, na época daquele seminário, nós estivemos lá e nós vimos quanta coisa que a própria escola já vinha realizando ali, até fizeram uma apresentação pra nós. Outro dia, eu recebi uma cartilha, que foi elaborada por uma menina... Não é nem uma cartilha, desculpe, a expressão não é essa não. Ela é uma professora do Riacho da Guia, do Encantado, professora do Município, que dentro daquele programa do "Historiando Alagoinhas", ela orientou os alunos e eles escreveram sobre a história do lugar deles, que é a história do Encantado. Eu fiquei muito emocionada, recebi esse livreto e guardei. Então, você vê, é claro que é uma diferença grande, por que a professora que conduz os seus alunos pra conhecer o seu lugar, o lugar onde eles nasceram, onde eles 
vivem, onde vivem os seus pais, os seus familiares, de onde eles tiram o sustento, mas com respeito por esse lugar, a ponto de escrever sobre ele, que o Encantado é um povoado do distrito do Riacho da Guia, aqui em Alagoinhas. E ficou uma coisa linda, a Secretaria de Educação deu apoio e publicou esse material, eu recebi um... Então, tudo isso é sinal que há uma diferença no trabalho que se realiza. Embora a gente diga que é uma diferença ainda pequena, mas é uma diferença que já existe e nós não temos dúvidas de que isso se deve também à existência de um curso, de um trabalho de nível superior com uma outra mentalidade, não é ? Porque podia ter um curso superior e até de pós- graduação, mas que tivesse uma mentalidade semelhante a que já acontece e não haveria mudanças.

Então, eu atribuo essas novidades que estão acontecendo aí, a disposição dos professores também de aprender, de querer avançar... (...) Eu atribuo a isso: a essa condução do nosso curso de Letras, a própria mudança do currículo com essa possibilidade de ter as Práticas Pedagógicas, depois o estágio em diferentes etapas, isso vai permitindo ao aluno um maior contato com aquela escola, com a comunidade, conhecendo mais aquela realidade, enquanto ele vai se preparando, aqui, pra o trabalho que vai acontecer depois.

Então, a tendência natural é que ele vá tendo mais segurança no que vai fazer, porque ele vai tendo o contato mais direto com esse estudante, vai conhecendo sua realidade, vai recebendo as orientações dos professores, aqui, e na escola. Com a questão das monografias no final do semestre, também ele vai tendo uma maior necessidade de estudar e de se aprofundar no conhecimento teórico e de estabelecer a relação entre o elemento teórico e o elemento prático. E eu considero que tudo isso é contributivo pra essa melhoria que a gente percebe. Acho que ainda estamos longe daquele ponto ideal, mas estamos caminhando para chegar lá. Com o Mestrado, que está começando ainda, (...) à medida que sai essa turma e que a gente vai avançando mais pra um doutorado, a qualificação dos professores que também está aí e é uma coisa muito importante que o professor esteja altamente qualificado. Vê o número grande de doutores que temos aí, agora, com a vontade de fazer? Ser doutor apenas, não é? Mas, com a vontade de realizar e de avançar esse trabalho de integração da pós com o curso de graduação. O curso de graduação, agora, já tendo essa divisão entre Vernáculas e Língua Estrangeira, eu acho um dado também positivo, porque cada área vai poder 
trabalhar mais especificamente sobre as suas necessidades. Então, isso tudo vai criando um lastro maior de preparo pra esses profissionais que vão sair daqui e eu acredito que a tendência natural é avançar. Agora, acho que é muito importante que se mantenha aquela linha de contato com a SEDUC ${ }^{3}$, agora, por exemplo, não foi possível participar da Jornada, mas por causa da diferença do calendário, não acredito que eles fossem criar um obstáculo pra participação.

JSPM: Eles nem souberam que queríamos participar.

IG: Pois é... Então, é preciso que se continue insistindo nessa inter-relação com a SEDUC e com a DIREC ${ }^{4}$, com as escolas do município e as escolas do Estado. (...) Procurar ter a melhor produção entre nós e levar sempre isso nessa troca, nesse intercâmbio.

Eu espero, inclusive, que se possa discutir aquela questão dos Núcleos, que as escolas tenham a possibilidade mais especifica de participação aqui, de acompanhamento dos trabalhos daqui, aquela discussão que já se começou a fazer, não é? Não apenas procurar para que os alunos possam ter a participação, lá, fazendo o Estágio, as observações de aula, mas que os professores possam participar, aqui, das oficinas, possam ter aqui os seminários e que isso seja definido, que isso seja organizado no calendário. Que tal dia da semana, que uma vez por mês, que eles tenham essa oportunidade de estar aqui conosco. Já pensou que coisa boa, se, por exemplo, a Secretaria de Educação estabelecesse esse acordo com a Faculdade? E nós teríamos, uma vez por mês, esses professores com a oportunidade de vir aqui fazer um seminário, um simpósio, a respeito de cultura, não é? Com o envolvimento do colegiado de Letras, do Mestrado de Crítica Cultural, nós só iríamos avançando, bastante avançando e enriquecendo e esse povo ia melhorar tanto, que ele não ia querer mais, não ia permitir mais, que nenhum gestor viesse e alterasse essa possibilidade de enriquecimento.

Uma coisa que me preocupa muito, Jailma, é o seguinte: nós temos um salário ridículo, não existe estímulo para o trabalho do professor, o professor não apenas fica desestimulado pra ir lá, mas a própria comunidade não respeita o trabalho que ele realiza. Hoje, tá esse clima terrível de violência, por uma mistura de situações, porque

\footnotetext{
${ }^{3}$ Secretaria Municipal de Educação de Alagoinhas.

${ }^{4}$ A entrevistada faz referência à DIREC 3, Diretoria Regional de Educação, situada em Alagoinhas.
} 
existem escolas onde o professor trabalha e trabalha bem. Então, por que essa diferença? Porque essas condições não são criadas efetivamente. Então, uma coisa que eu sinto é que, se houvesse esse trabalho integrado mesmo da Universidade com a Educação Básica, podendo dar esse suporte, esse suporte teórico e metodológico ao professor, ele ia se sentir muito mais à vontade.

Ás vezes o professor tá lá, fazendo um trabalho, eu não queria usar essa expressão, mas vou usar, um trabalho ridículo, que hoje não cabe mais, você tá trabalhando com o aluno pra tá decorando o que é substantivo, adjetivo, pronome, verbo, mas é ainda assim que se faz. Agora, depois você põe lá o texto, não sabe identificar, nem fazer a diferença entre um e outro, mas tá fazendo isso... Por quê? Porque não recebeu uma outra orientação pra fazer um trabalho diferente. Se o fundamental é a leitura, ora meu Deus do céu, eu posso ler um jornal, eu posso ler uma piada. Não é? Eu posso ler uma charge. Eu estou pondo esse menino pra descortinar quantos outros mundos, não é? Através do desenho, não é? Através da imagem, através da caricatura. Então, quantas coisas que podem ser lidas? Eu não sou obrigada a ler apenas aquele texto que tá ali naquele livro de leitura e que muitas vezes é um livro que já foi composto dentro de outras situações e até com algumas marcas de discriminação, de preconceito, de tudo que a gente sabe que ainda existe.

Então, eu sinto isso, que nós precisamos não apenas manter essa linha de trabalho, mas ir cada vez mais ampliando esses nossos horizontes, no sentido de poder atingir efetivamente essa comunidade escolar, pra que ela sinta que esse espaço é o espaço dela. Aqui, onde ela venha beber nessa fonte e se beneficiar dessas informações... Não venha aqui nem por castigo, nem por que foi paga, nem por que... não! Vir pelo prazer, eu digo vir, mas tanto pode ser vir pra cá quanto pode ser a gente ir pra lá, contanto que esse intercâmbio se dê de uma forma bem agradável, como eu senti lá na escola Maria José Bastos, naquele dia, que o pessoal estava à vontade conosco. Como você não pôde ir no dia, mas quem foi se sentiu muito bem lá na escola Nova Esperança. E quando eu disse a você: "vamos à escola Nova Esperança", por quê? Por que eu sei do trabalho maravilhoso que eles fazem lá. Porque tem a questão da Fundação do Caminho que trabalha com os meninos cegos, surdos, mas mesmo com os chamados "normais", o trabalho é um trabalho muito interessante. Então, nós temos tudo isso aí e essa gente aberta pra nos receber e a gente precisa aproveitar essas oportunidades. 
E, incrementando, esse intercâmbio do Mestrado com o colegiado não pode de forma alguma diminuir, só tem é que aumentar cada vez mais. Os próprios professores vão sentindo necessidade de ir se melhorando cada vez mais, quem correu pra fazer Mestrado, agora tá correndo pra fazer o doutorado. Então, esse nível vai também dando uma outra condição de participar de uma discussão, porque, às vezes, a pessoa fica até acanhada de participar de uma discussão, porque diz: "mas aqui só tem doutor, o que é que eu vou dizer", não é? Às vezes, até tem a informação, mas fica acanhada de dizer algo que não seja apropriado, não é?

Então, eu sinto que esse é o nosso caminho: de continuar avançando e continuar buscando as escolas pra estabelecer, pra se oferecer como oportunidade de discussão e trabalhar, do ponto de vista teórico, essas questões da cultura, pra que a gente possa entender melhor que cultura nem é algo único, não tem um conceito único, e nem é algo estático ... Tem sempre essa possibilidade da, como é que eu diria, do entendimento, do entendimento múltiplo, da variabilidade, e que a gente tenha a condição de saber que isso aqui é mais adequado pra essa situação, e esse outro conceito mais adequado pra essa situação aqui, mas que eu tenha segurança no que vou dizer, porque eu estou devidamente fundamentado.

JSPM: Ok. Iraci, eu quero agradecer pela entrevista concedida. A Iraci tem um tempo muito corrido, precioso, pra conseguir esse espaço não foi fácil. Então, eu quero agradecer muito a sua disponibilidade.

Transcrição de Jailma dos Santos Pedreira Moreira, Luane Martins e Silvana Lianda.

RECEBIDO EM: 04 de maio de 2011

APROVADO EM: 14 de junho de 2011 